\title{
Freshwater microcrustaceans (Cladocera: Anomopoda and Ctenopoda, Copepoda: Cyclopoida and Calanoida) in the highly urbanized Metropolitan Manila area (Luzon, Philippines)
}

\author{
Erica Silk P. Dela Paz ${ }^{1,2}$, Mark Louie D. Lopez ${ }^{1,4}$, Christian Irvin Harvey A. David ${ }^{2}$, Dave Ryan
} A. Dela Cruz ${ }^{2}$, Gian Alfonso A. Viernes ${ }^{2}$, Jac Fritgerald Wong ${ }^{2}$, Rey Donne S. Papa ${ }^{1,2,3}$

1 The Graduate School, University of Santo Tomas, Manila 1015, Philippines. 2 Department of Biological Sciences, College of Science, University of Santo Tomas, España, Manila 1015, Philippines. 3 Research Center for Natural and Applied Sciences, University of Santo Tomas, España, Manila 1015, Philippines. 4 Research Unit, Philippine Science High School, Agham Road, Diliman, Quezon City 1101, Philippines.

Corresponding author: Rey Donne S. Papa, rspapa@ust.edu.ph

\begin{abstract}
Despite the increasing interest in studying Cladocera and Copepoda in Philippine freshwaters, there is a need to update our knowledge on its taxonomy and distribution in highly urbanized areas, such as Metropolitan Manila. This paper presents an updated listing of freshwater microcrustaceans and their distribution in Metropolitan Manila, considering the continued deterioration of water quality and increased urbanization in many areas since the last comprehensive study on these taxa in 1950s. We collected water samples from 33 freshwater sites in Metropolitan Manila and 23 of which were found to contain microcrustacean zooplankton. A total of 13 species were identified including two new locality records for C. cornuta and D. dubium in Pasig River. All 8 cladocerans, we identified have already recorded in previous studies while 3 cyclopoid copepods are new records for Metropolitan Manila. Furthermore, $16 \%$ of all known freshwater microcrustacean zooplankton species in the Philippines are found in Metropolitan Manila, including the Luzon-endemic Filipinodiaptomus insulanus collected from man-made reservoirs in less-disturbed habitats (an urban wildlife park, golf course and eco-park). Other identified species such as Thermocyclops taihokuensis may serve as indicator for high levels of nutrient. These results point to the importance of monitoring urban aquatic biodiversity for their potential in determining aquatic ecosystem health and of maintaining urban aquatic sanctuaries which may serve as alternative habitat for flora and fauna in rapidly developing urban centers such as Metropolitan Manila.
\end{abstract}

\section{Key words}

Microcrustacean; zooplankton; urban; Metro Manila; new records; distribution; tropics.

Academic editor: Sameer Padhye | Received 27 March 2018 | Accepted 22 August 2018 | Published 14 September 2018

Citation: Dela Paz ESP, Lopez ML, David CIHA, Dela Cruz DRA, Viernes GAA, Wong JF, Papa RDS (2018) Freshwater microcrustaceans (Cladocera: Anomopoda and Ctenopoda, Copepoda: Cyclopoida and Calanoida) in the highly urbanized Metropolitan Manila area (Luzon, Philippines). Checklist 14 (5): 751-762, https://doi.org/10.15560/14.5.751

\section{Introduction}

Metropolitan Manila, with a land area of $633 \mathrm{~km}^{2}$ (Manasan and Mercado 1999), is the most populated region in the Philippines due to the active migration of people from rural areas seeking livelihood in the metropolitan area after the Second World War (Vallejo et al. 2009). Its human population increases $1.1 \%$ every year, with a population of nearly 22 million as of 2012 (Zoleta 2000, Vallar et al. 
2015). The increase in population and rapid urbanization have raised several environmental concerns, including the deterioration of environmental quality, particularly in freshwater ecosystems (Qian et al. 2000). According to Orozco and Zafaralla (2012), most rivers and streams in Metropolitan Manila are polluted due to urban use, various human activities and high discharge of organic materials from industrial and residential areas. Due to the growing problem of degrading water resources in the Philippines, including the dense area of Metropolitan Manila, several programs and policies were mandated to monitor and provide clean water (Rola et al. 2015). The implementation of policies involves the protection of the water bodies from pollution and provide water quality management to avoid loss biodiversity in these types of ecosystems.

Cladocera and Copepoda are widely distributed planktonic microcrustaceans that predominantly occur in freshwater. These taxa include littoral, pelagic and benthic species, which perform key roles in the food web. They have great value for fisheries, and in maintaining ecosystem processes. They also can be used as environmental indicators of pollution (Parmar et al. 2016), as they readily respond to changes in water quality. The changes in population density, species richness and community structure of cladocerans and copepods are mostly affected by the physicochemical conditions of the water in which they live. The reproduction and survival rates of cladocerans and copepods have a seasonal pattern that are highly dependent on favorable environmental conditions. Due to various anthropogenic activities, upwellings and runoffs of nutrients from tributaries, the trophic state of freshwater habitats may be altered. As such, these environmental changes influence the timing, reproduction rate, and survival rate of these groups of aquatic animals (Varpe et al. 2007, Tordesillas et al. 2016).

Extensive research on the distribution of freshwater microcrustacean in the Philippines started as early as 19th century with the Wallacea-Tressler Expedition that focused on the Oriental cladoceran and copepod species in Southeast Asia (Wright 1928, Kiefer 1930, Brehm 1938, Kiefer 1938, Woltereck et al. 1941, Brehm 1942). The earliest record of a microcrustacean species in Metropolitan Manila was by Marsh (1932), who described an endemic cyclopoid copepod, Thermocyclops philippinensis. This was followed in 1954 by the first inventory of the freshwater cladocerans by Cheng and Clemente (1954). The records of Philippine microcrustacean zooplankton was updated through the work of Uéno (1966), who recorded 8 cladoceran and 2 copepod species from Lake Taal (Luzon Island), Petersen and Carlos (1984) with 15 cladoceran and 25 copepod species from major lakes in Luzon, and Lake Lanao in Mindanao. The most comprehensive works are Mamaril and Fernando (1978), and Mamaril (1986, 2001), who listed 125 freshwater microcrustacean species (49 cladocerans and 9 copepods) from the various bodies of freshwater in the archipelago. Despite the initiatives done by several researchers in the past to document for the diversity of microcrustaceans in the country, our knowledge of them is still rather limited. Thereafter, several studies on the local distributions of cladoceran and copepod species had been conducted to address these gaps and revised some taxonomic issues of misidentified species. Several researchers managed to collect samples from poorly unexplored areas for microcrustacean species in Luzon (Tuyor and Baay 2001, Mamaril 2001, Aquino 2008, Papa and Hołyńska 2013), major islands in Visayas (Dela Paz et al. 2016a, 2016b), in selected areas in Mindanao (Tuyor and Baay 2001, Pascual 2014, Dela Paz 2016b). Collections were also conducted in groundwater dependent ecosystems in the country (Cavite et al. 2017, Lopez et al. 2017a, b). The most recent update on the taxonomic status and distribution of freshwater microcrustacean zooplankton revealed the presence of 81 species in the Philippines including 55 cladocerans and 36 copepods (Lopez et al. 2017a). However, we still lack an updated listing of freshwater microcrustaceans in Metropolitan Manila. As such, information on the species composition of microcrustaceans (Cladocera and Copepoda) in Metropolitan Manila collected under the present environmental conditions in the area is extremely lacking. In this paper, we provide an updated species list and provide information on the distribution of freshwater microcrustaceans (Cladocera and Copepoda) in an urban area at Metropolitan Manila.

\section{Methods}

Study sites. Our samples were collected from June to July 2016 from 33 freshwater sites including ponds, rivers, small streams, and canals, and lagoons in Metropolitan Manila. Details on selected physico-chemical characteristics and location of the selected sampling sites are presented in Figure 1 and Table A1 in the Appendix.

The collection of cladoceran and copepod was done using a conical plankton net $(70 \mu \mathrm{m})$ which was towed vertically or horizontally, depending on the depth of the sampling site. The samples were then preserved with $70 \%$ ethanol, and then stored in labeled screw-capped bottles. The coordinates of the sample sites were obtained using a GPS receiver and mapped using QGIS software Version 2.18.11 using Luzon 1911 as the geodetic datum.

Material examination. In the laboratory, we filtered the samples using $33 \mu \mathrm{m}$ mesh filter. Samples were stained with Rose Bengal dye in $70 \%$ (v/v) ethanol. The samples were then sorted according on their major taxonomic groups and dissected with the aid of Olympus CX21 Compound Microscope and Swift Stereomicroscope. Specimens were mounted in glycerine. Taxonomic keys and scientific illustrations by Goulden (1968), Fryer (1968), Mamaril Sr. and Fernando (1978), Lai and Fernando (1980), Petersen and Carlos (1984), Berner (1985), Mamaril (1986), Korovchinsky (1992), Smirnov (1996), Dussart and Defaye (2001), Dumont and Negrea (2002), 


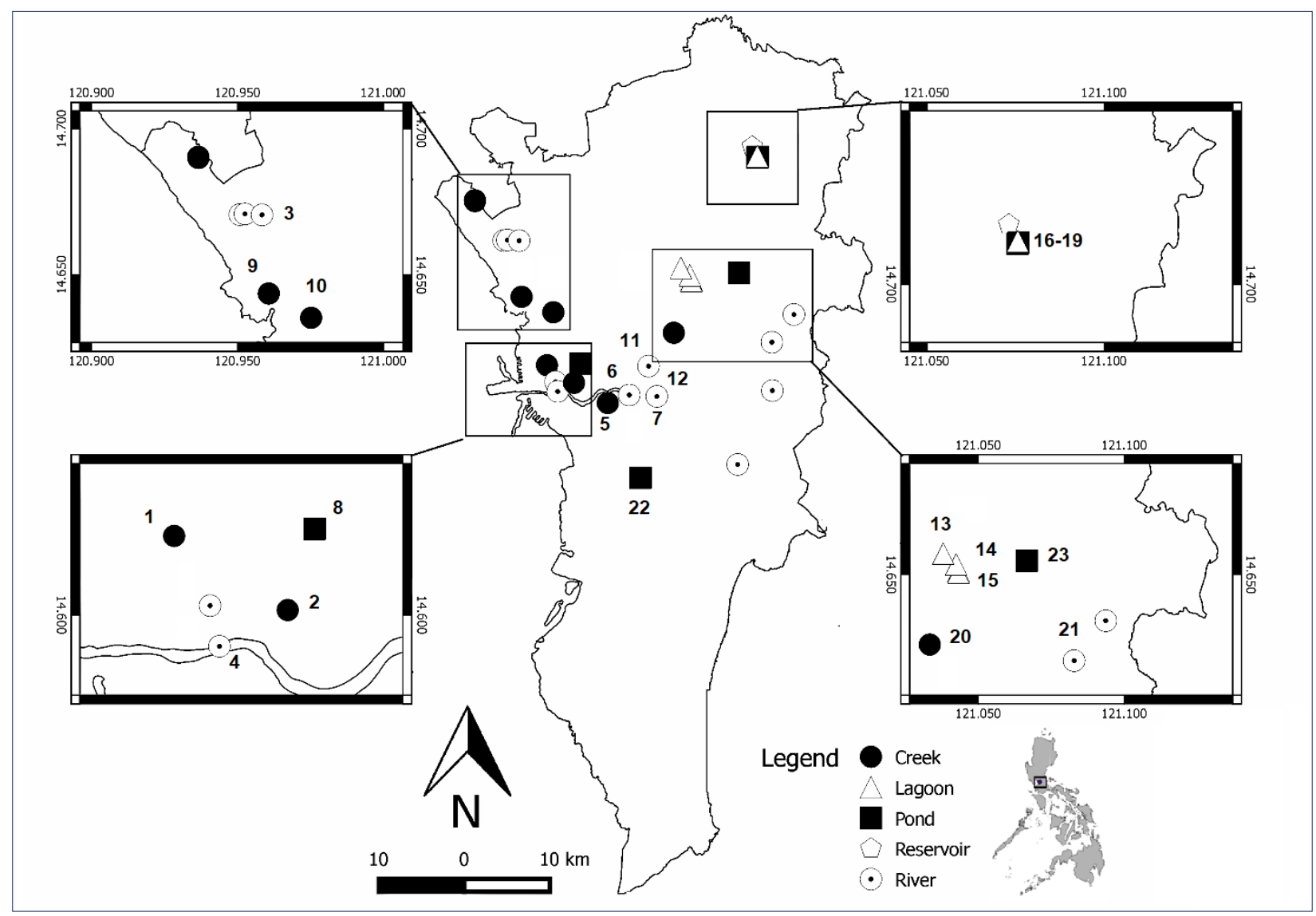

Figure 1. Map of the selected sampling localities in Metropolitan Manila. Number of sampling site in the Appendix, Table A1.

Fernando (2002), Korovchinsky (2002), Boxshall and Halsey (2004), Hołyńska (2000), Mirabdullayev et al. (2003), Papa et al. (2012) Pascual et al. (2014) and Dela Paz et al. (2016a, 2016b) were used for the species-level identification of specimens.

All voucher specimens were deposited at the University Santo Tomas, Zooplankton Reference Collection (UST-ZRC).

\section{Results}

Thirteen species of freshwater microcrustaceans belonging to 7 families were identified in this study. This includes 8 cladocerans from 5 families: Bosminidae Baird, 1845, Chydoridae Stebbing, 1902, Daphniidae Straus, 1820, Moinidae Goulden, 1968, and Sididae Baird, 1850. In addition, 3 species of cyclopoid copepods belonging to family Cyclopidae Rafinesque, 1815 and 2 species of calanoid copepods belonging to family Diaptomidae Baird, 1850. Complete list of all identified species and the sampling localities where they were collected is shown in Table 1.

Subphylum Crustacea Brünnich, 1772

Class Branchiopoda Latreille, 1817

Superorder Cladocera Latreille, 1829

Order Anomopoda Stebbing, 1902

Family Bosminidae Baird, 1845

Bosmina fatalis (Baird, 1864)
Materials examined. Philippines: Luzon: Manila: Kalayaan Creek $\left(14.6900^{\circ} \mathrm{N}, 120.9366^{\circ} \mathrm{E}\right)$, coll. DRA Dela Cruz, GAA Viernes, JF Wong, ESP Dela Paz and ML Lopez, June 2016 (UST-ZRC 0097-0098, 2 spec.). Estero de la Reina $\left(14.6011^{\circ} \mathrm{N}, 120.9763^{\circ} \mathrm{E}\right)$, coll. DRA Dela Cruz, GAA Viernes, JF Wong, ESP Dela Paz and ML Lopez, June 2016 (UST-ZRC 0099A-0099F, 4 spec.). Marikina River $\left(14.6342^{\circ} \mathrm{N}, 121.0936^{\circ} \mathrm{E}\right)$, coll. DRA Dela Cruz, GAA Viernes, JF Wong, ESP Dela Paz and ML Lopez, June 2016 (UST-ZRC 0100A-B, 2 spec.).

Short description. The head is large and rectangular in shape, with no clear demarcation between the head and body along the dorsal surface. Head shield is present. The eye is small near the rostrum. The long rostrum is fused with the immobile antennules, with a slight concavity between the 2 parts. The antennules have a characteristic pointed projection along the midline. The postabdominal claw is almost straight with 6 spines and the distal part finely ciliated. Morphological characteristics concur with the descriptions and illustrations of Fernando (1992) and Pascual et al. (2014).

Ecological distribution. Bosmina fatalis is widely distributed in lakes, rivers, creeks, and reservoirs. This species is a primary grazer in the freshwater habitats and has a good defensive mechanism (akinesis) against its predator which allows them to live in the pelagic zone despite of its small body size (Rizo et al. 2017). 
Table 1. List of observed Cladocera and Copepoda and distribution in Metropolitan Manila.

\begin{tabular}{|c|c|c|c|c|c|c|c|c|c|c|c|c|c|c|c|c|c|c|c|c|c|c|c|}
\hline \multirow{2}{*}{ Taxon } & \multicolumn{23}{|c|}{ Sampling localities } \\
\hline & 1 & 2 & 3 & 4 & 5 & 6 & 7 & 8 & 9 & 10 & 11 & 12 & 13 & 14 & 15 & 16 & 17 & 18 & 19 & 20 & 21 & 22 & 23 \\
\hline \multicolumn{24}{|l|}{ Family Bosminidae } \\
\hline Bosmina fatalis (Baird, 1864) & $t$ & & & & & $\dagger$ & & & & & & & & & & & & & & & $\dagger$ & & \\
\hline \multicolumn{24}{|l|}{ Family Chydoridae } \\
\hline Chydorus cf. sphaericus (Mueller, 1785) & & & & & & & & & & & & & $\dagger$ & & & & & & & & & & \\
\hline \multicolumn{24}{|l|}{ Family Daphniidae } \\
\hline Ceriodaphnia cornuta (Sars, 1885) & & & & & & & $\dagger$ & & & & $\dagger$ & & & & & $t$ & $\dagger$ & & & & $\dagger$ & $\dagger$ & \\
\hline \multicolumn{24}{|l|}{ Family Moinidae } \\
\hline Moina Micrura (Kurz, 1875) & & & $t$ & & & $t$ & $t$ & & & & & & & $\dagger$ & $\dagger$ & & & & & & $\dagger$ & $\dagger$ & \\
\hline Moinodaphnia macleayi (King, 1853) & & & $\dagger$ & & & & $\dagger$ & $t$ & & & & & & & $\dagger$ & & & & & $\dagger$ & $\dagger$ & & \\
\hline \multicolumn{24}{|l|}{ Family Sididae } \\
\hline Diaphanosoma dubium (Manuilova, 1964) & & & & $\dagger$ & & & $\dagger$ & & & & & & $\dagger$ & & $\dagger$ & & $\dagger$ & $\dagger$ & & & & & \\
\hline Diaphanosoma excisum (Sars, 1885) & & & & + & & & & & & & & $\dagger$ & $\dagger$ & & & & & & $\dagger$ & & $\dagger$ & & \\
\hline Diaphanosoma sarsi (Richard, 1894) & & & & & & & & $\dagger$ & & & & & $\dagger$ & & $\dagger$ & $\dagger$ & & $\dagger$ & & & $\dagger$ & & \\
\hline \multicolumn{24}{|l|}{ Family Cyclopidae } \\
\hline Mesocyclops aspericornis (Daday, 1906) & & & + & + & & + & & $\dagger$ & & & & & & & $\dagger$ & & & & & & & & \\
\hline Thermocyclops decipiens (Kiefer, 1929) & & & & & & & $\dagger$ & $\dagger$ & & & & & 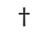 & & $\dagger$ & & 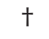 & & $\dagger$ & t & & & \\
\hline Thermocyclops taihokuensis (Harada, 1931) & $\dagger$ & & $\dagger$ & & & & & & & & & $\dagger$ & & $\dagger$ & & $\dagger$ & $\dagger$ & $\dagger$ & & & & & \\
\hline Cyclopoid copepodite & $\dagger$ & & $t$ & $\dagger$ & & & $\dagger$ & & $\dagger$ & & $\dagger$ & $\dagger$ & & $\dagger$ & & $\dagger$ & $\dagger$ & $\dagger$ & $\dagger$ & $\dagger$ & $\dagger$ & $\dagger$ & \\
\hline \multicolumn{24}{|l|}{ Family Diaptomidae } \\
\hline Arctodiaptomus dorsalis (Marsh, 1907) & & & & & & & $t$ & & & & & & & & & & & & & & & & \\
\hline Filipinodiaptomus insulanus (Wright, 1927) & & & & & & & & & & & & & $t$ & & $t$ & $t$ & & & & & & & \\
\hline
\end{tabular}

Family Chydoridae Dybowski \& Grochowski, 1894

\section{Chydorus cf. sphaericus (Mueller, 1785)}

Materials examined. Philippines: Luzon: Manila: Ninoy Aquino Parks and Wildlife Lagoon $\left(14.6512^{\circ} \mathrm{N}\right.$, 121.0432 ${ }^{\circ}$ E), coll. DRA Dela Cruz, GAA Viernes, JF Wong, ESP Dela Paz and ML Lopez, June 2016, (USTZRC 0101A-C, 3 spec.).

Short description. The body is hemispherical in shape, with no clear demarcation between the head and the body dorsally. The head shield is present. The rostrum is relatively longer than the antennule. A pair of 3-segmented second antennules with 3 projecting setae is found inferior to the antennule. The terminal claw is almost straight, with small spines. The postabdomen is short with pointed denticles on the postero-ventral margin. The morphological characteristics concur with the descriptions and illustrations of Fryer (1968), Petersen and Carlos (1984), Fernando (1992), Smirnov (1996), and Dumont and Negrea (2002).

Ecological distribution. Chydorus cf. sphaericus is present in lakes, reservoirs, and pools. This species is found in the littoral vegetation and pelagic area but can survive eutrophic conditions.

Family Daphniidae Stratus, 1820

\section{Ceriodaphnia cornuta (Sars, 1885)}

Materials examined. Philippines: Luzon: Manila: La Mesa Dam $\left(14.7168^{\circ} \mathrm{N}, 121.0731^{\circ} \mathrm{E}\right)$, coll. DRA Dela Cruz, GAA Viernes, JF Wong, ESP Dela Paz and ML Lopez, June 2016 (UST-ZRC 0102A-F, 6 spec.) La Mesa Ecopark pond $1\left(14.7113^{\circ} \mathrm{N}, 121.0756^{\circ} \mathrm{E}\right)$, coll. DRA
Dela Cruz, GAA Viernes, JF Wong, ESP Dela Paz and ML Lopez, June 2016 (UST-ZRC 0103A-B, 2 spec.). Marikina River $\left(14.6342^{\circ} \mathrm{N}, 121.0936^{\circ} \mathrm{E}\right)$, coll. DRA Dela Cruz, GAA Viernes, JF Wong, ESP Dela Paz and ML Lopez, June 2016 (UST-ZRC 0104 A-C, 3 spec.). Pasig River $\left(14.5604^{\circ} \mathrm{N}, 121.0659^{\circ} \mathrm{E}\right)$, coll. DRA Dela Cruz, GAA Viernes, JF Wong, ESP Dela Paz and ML Lopez, June 2016 (UST-ZRC 0105, 1 spec.). San Juan River $\left(14.6088^{\circ} \mathrm{N}, 121.0220^{\circ} \mathrm{E}\right)$, coll. DRA Dela Cruz, GAA Viernes, JF Wong, ESP Dela Paz and ML Lopez, June 2016 (UST-ZRC 106, 1 spec.). Washington SyCip Park pond $\left(14.5539^{\circ} \mathrm{N}, 121.0180^{\circ} \mathrm{E}\right)$, coll. DRA Dela Cruz, GAA Viernes, JF Wong, ESP Dela Paz and ML Lopez, June 2016, (UST-ZRC 107 spec.).

Short description. A cervical sinus is evident between the head and the body. The head is small and round in shape, with a pointed rostrum and pigmented patch of ocellus. The head shield is present. The antennules are fused with the ventral portion of the head. Fine ciliation is present at the postabdominal claws. The morphological characteristics concur with the descriptions and illustrations provided by Petersen and Carlos (1984), Berner (1985), Fernando (1992) and Dumont and Negrea (2002).

Ecological distribution. Ceriodaphnia cornuta is present in lakes and a reservoir. This species is a primary grazer in the freshwater habitats and has a great competitive power against with larger grazers (Rizo et al. 2017).

Family Moinidae Goulden 1968

\section{Moina micrura (Kurz, 1875)}

Materials examined. Philippines: Luzon: Manila: Estero 
de la Reina $\left(14.6011^{\circ} \mathrm{N}, 120.9763^{\circ} \mathrm{E}\right)$, coll. DRA Dela Cruz, GAA Viernes, JF Wong, ESP Dela Paz and ML Lopez, June 2016 (UST-ZRC 0108A-B, 2 spec.). Marikina River $\left(14.6342^{\circ} \mathrm{N}, 121.0936^{\circ} \mathrm{E}\right)$, coll. DRA Dela Cruz, GAA Viernes, JF Wong, ESP Dela Paz and ML Lopez, June 2016 (UST-ZRC 0109, 1 spec.). Pasig River $\left(14.5604^{\circ} \mathrm{N}, 121.0659^{\circ} \mathrm{E}\right)$, coll. DRA Dela Cruz, GAA Viernes, JF Wong, ESP Dela Paz and ML Lopez, June 2016 (UST-ZRC 0110A-C, 3 spec.). Veterans Memorial Medical Center lagoons $\left(14.6535^{\circ} \mathrm{N}, 121.0424^{\circ} \mathrm{E}\right.$ and $\left.14.6571^{\circ} \mathrm{N}, 121.0380^{\circ} \mathrm{E}\right)$, coll. DRA Dela Cruz, GAA Viernes, JF Wong, ESP Dela Paz and ML Lopez, June 2016 (UST-ZRC, 0111A-E, 5 spec.). Washington SyCip Park pond $\left(14.5539^{\circ} \mathrm{N}, 121.0180^{\circ} \mathrm{E}\right)$ coll. DRA Dela Cruz, GAA Viernes, JF Wong, ESP Dela Paz and ML Lopez, June 2016 (UST-ZRC 0112A-D, 4 spec.).

Short description. The head is round with large eye. Sensory papillae are prominent. The proximal part of the postabdominal claw is finely ciliated and with a pincer-like structure that is also called "basaldron". Sharp denticles are evident in the postero-ventral margin. The morphological characteristics concur with the descriptions and illustrations provided by Petersen and Carlos (1984), Fernando (1992), Goulden (1968), Dumont and Negrea (2002), and Pascual et al. (2014).

Ecological distribution. Moina micrura is present in lakes, rivers, pools, and fish ponds. It is pelagic.

\section{Moinodaphnia macleayi (King, 1853)}

Materials examined. Philippines: Luzon: Manila: creek in Muñoz $\left(14.6574^{\circ} \mathrm{N}, 121.0157^{\circ} \mathrm{E}\right)$, coll. DRA Dela Cruz, GAA Viernes, JF Wong, ESP Dela Paz and ML Lopez, June 2016 (UST-ZRC 0114A-D, 4 spec.). Marikina River $\left(14.5967^{\circ} \mathrm{N}, 121.0830^{\circ} \mathrm{E}\right)$, coll. DRA Dela Cruz, GAA Viernes, JF Wong, ESP Dela Paz and ML Lopez, June 2016 (UST-ZRC 0113A-C, 3 spec.). Pond in the UST Botanical Garden $\left(14.6101^{\circ} \mathrm{N}, 120.9885^{\circ} \mathrm{E}\right)$, coll. DRA Dela Cruz, GAA Viernes, JF Wong, ESP Dela Paz and ML Lopez, June 2016 (UST-ZRC 0117, $1 \mathrm{spec}$.). Pasig River $\left(14.5946^{\circ} \mathrm{N}, 121.0125^{\circ} \mathrm{E}\right.$ and $14.5959^{\circ}$ N, $120.9771^{\circ} \mathrm{E}$ ), coll. DRA Dela Cruz, GAA Viernes, JF Wong, ESP Dela Paz and ML Lopez, June 2016 (UST-ZRC0115A-H, 8 spec.). Veterans Memorial Medical Center $\left(14.6571^{\circ} \mathrm{N}, 121.0380^{\circ} \mathrm{E}\right)$, coll. DRA Dela Cruz, GAA Viernes, JF Wong, ESP Dela Paz and ML Lopez, June 2016 (UST-ZRC 0118A-C, 3 spec.). Tullahan River $\left(14.6705^{\circ} \mathrm{N}, 120.9584^{\circ} \mathrm{E}\right)$, coll. DRA Dela Cruz, GAA Viernes, JF Wong, ESP Dela Paz and ML Lopez, June 2016 (UST-ZRC 0116-0117, 2 spec.).Short description. The head and the body are separated by a groove. The head is small and slightly triangular in shape. The antennule has a long projecting hair with 9 sensory papillae present at the distal end. The denticles are present at the postero-ventral margin. The morphological characteristics concur with the descriptions and illustrations provided by Petersen and Carlos (1984), Fernando
(1992) and Dumont and Negrea (2002).

Ecological distribution. Moinodaphnia macleayi is present in lakes, dams, creek, ponds and pools. This swimming cladoceran is found in the pelagic area.

Order Ctenopoda Sars, 1865

Family Sididae Baird, 1850

\section{Diaphanosoma dubium (Manuilova, 1964)}

Materials examined. Philippines: Luzon Is.: Manila: Veterans Memorial Medical Center lagoon $\left(14.6571^{\circ} \mathrm{N}\right.$, 121.0380 E), coll. DRA Dela Cruz, GAA Viernes, JF Wong, ESP Dela Paz and ML Lopez, June 2016 (USTZRC 0124A-D, 4 spec.). La Mesa Ecopark pond 1 $\left(14.7113^{\circ} \mathrm{N}, 121.0756^{\circ} \mathrm{E}\right)$, coll. DRA Dela Cruz, GAA Viernes, JF Wong, ESP Dela Paz and ML Lopez, June 2016 (UST-ZRC 0119A-C, 3 spec.). La Mesa Ecopark pond $2\left(14.7117^{\circ} \mathrm{N}, 121.0759^{\circ} \mathrm{E}\right)$ coll. DRA Dela Cruz, GAA Viernes, JF Wong, ESP Dela Paz and ML Lopez, June 2016 (UST-ZRC 0120A-F, 6 spec.). Pasig River $\left(14.5604^{\circ} \mathrm{N}, 121.0659^{\circ} \mathrm{E}\right)$, coll. DRA Dela Cruz, GAA Viernes, JF Wong, ESP Dela Paz and ML Lopez, June 2016 (UST-ZRC 0123A-D, 4 spec.). Navotas River $\left(14.6436^{\circ} \mathrm{N}, 120.9607^{\circ} \mathrm{E}\right)$, coll. DRA Dela Cruz, GAA Viernes, JF Wong, ESP Dela Paz and ML Lopez, June 2016 (UST-ZRC 0121A-B and 0125, 3 spec.). Ninoy Aquino Parks \& Wildlife Center lagoon $\left(14.6507^{\circ} \mathrm{N}\right.$, $121.0432^{\circ}$ E) coll. DRA Dela Cruz, GAA Viernes, JF Wong, ESP Dela Paz and ML Lopez, June 2016 (USTZRC 0122A-B, 2 spec.).

Short description. The head is coned-shape protruding dorsally occupying almost $1 / 2$ of the body. A prominent eye is present near at the ventral margin. The posteroventral bears ungrouped marginal spines and setules. The morphological characteristics concur with the descriptions and illustrations provided by Fernando (1992) and Pascual et al. (2014).

Ecological distribution. Diaphanosoma dubium is present in lakes, rivers, and pools. This fast-swimming cladoceran inhabits the pelagic area and can survive variety of water environmental conditions (i.e. trophic status and temperature) (Rizo et al. 2017).

\section{Diaphanosoma excisum (Sars, 1885)}

Materials examined. Philippines: Luzon: Manila: creek in Tomas Morato Avenue beside Creekside Square $\left(14.6260^{\circ} \mathrm{N}, 121.0334^{\circ} \mathrm{E}\right)$, coll. DRA Dela Cruz, GAA Viernes, JF Wong, ESP Dela Paz and ML Lopez, June 2016 (UST-ZRC 0130A-B, 2 spec.). Ninoy Aquino Parks and Wildlife Lagoon $\left(14.6512^{\circ} \mathrm{N}, 121.0432^{\circ} \mathrm{E}\right)$, coll. DRA Dela Cruz, GAA Viernes, JF Wong, ESP Dela Paz and ML Lopez, June 2016 (UST-ZRC 0129A-C, 3 spec.) La Mesa Ecopark Lagoon (14.7121 $\left.{ }^{\circ} \mathrm{N}, 121.0756^{\circ} \mathrm{E}\right)$, coll. DRA Dela Cruz, GAA Viernes, JF Wong, ESP Dela Paz and ML Lopez, June 2016 (UST-ZRC 0126A-D, 4 spec.). Marikina River $\left(14.6342^{\circ} \mathrm{N}, 121.0936^{\circ} \mathrm{E}\right)$, coll. 
DRA Dela Cruz, GAA Viernes, JF Wong, ESP Dela Paz and ML Lopez, June 2016 (UST-ZRC 0127). Navotas River $\left(14.6436^{\circ} \mathrm{N}, 120.9607^{\circ} \mathrm{E}\right)$, coll. DRA Dela Cruz, GAA Viernes, JF Wong, ESP Dela Paz and ML Lopez, June 2016 (UST-ZRC 0128, 1 spec.).

Short description. The head is almost rectangular in shape, with a convex dorsal portion with eye near at the ventral margin. The carapace is oval shape. The posteroventral margin bears narrow free flap and ungrouped marginal spines. The postabdominal claw bears 3 spines, with short proximal spine and the long distal spine. The morphological characteristics concur with the descriptions and illustrations provided by Mamaril Sr. and Fernando (1978), Fernando (1992), Korovchinsky (2002), Dumont and Negrea (2002), and Pascual et al. (2014).

Ecological distribution. Diaphanosoma excisum is present in lakes, reservoirs, rivers, creeks, and pools. This fast swimmer cladoceran inhabits the pelagic area and can survive variety of water environmental conditions (i.e. trophic status and temperature) (Rizo et al. 2017).

\section{Diaphanosoma sarsi (Richard, 1894)}

Materials examined. Philippines: Luzon: Manila La Mesa Ecopark pond $2\left(14.7117^{\circ} \mathrm{N}, 121.0759^{\circ} \mathrm{E}\right)$ coll. DRA Dela Cruz, GAA Viernes, JF Wong, ESP Dela Paz and ML Lopez, June 2016 (UST-ZRC 0132A, 1 spec.). Ninoy Aquino Parks and Wildlife lagoon $\left(14.6507^{\circ} \mathrm{N}\right.$, 121.0432 ${ }^{\circ}$ E), coll. DRA Dela Cruz, GAA Viernes, JF Wong, ESP Dela Paz and ML Lopez, June 2016 (USTZRC 0134A-C, 3 spec.). La Mesa Dam (14.7168 ${ }^{\circ}$, $\left.121.0731^{\circ} \mathrm{E}\right)$, coll. DRA Dela Cruz, GAA Viernes, JF Wong, ESP Dela Paz and ML Lopez, June 2016 (USTZRC 0131A-C). Marikina River (14.5967 N, $121.0830^{\circ}$ E), coll. DRA Dela Cruz, GAA Viernes, JF Wong, ESP Dela Paz and ML Lopez, June 2016 (UST-ZRC 0133AC, 3 spec.).

Short description. The head is rectangular to nearly round in shape. A large eye is present, near the ventral margin of the head. The second antenna is long which bifurcates to a dorsal and ventral swimming setae. The broad free flap at the postero-ventral margin bears both feathered and naked setae; postero-ventral margin contains ungrouped marginal spines. The postabdominal claw bears 3 spines, with short proximal spine and the long distal spine. The morphological characteristics concur with the descriptions and illustrations provided by Fernando (1992), Dumont and Negrea (2002) and Pascual et al. (2014).

Ecological distribution. Diaphanosoma sarsi is present in lakes, rivers, pools, and swamps. This fast swimmer cladoceran inhabits the pelagic area and can survive variety of water environmental conditions (i.e. trophic status and temperature) (Rizo et al. 2017).

Class Maxillopoda Dahl, 1956
Subclass Copepoda Milne-Edwards, 1840

Order Cyclopoida Burmeister, 1835

Family Cyclopidae Rafinesque, 1815

Subfamily Cyclopinae Rafinesque, 1815

\section{Mesocyclops aspericornis (Daday, 1906)}

Materials examined. Philippines: Luzon: Manila: pond at the UST Botanical Garden $\left(14.6101^{\circ} \mathrm{N}, 120.9885^{\circ} \mathrm{E}\right)$, coll. DRA Dela Cruz, GAA Viernes, JF Wong, ESP Dela Paz and ML Lopez, June 2016 (UST-ZRC 0180A-B, 1 spec.). Navotas River (14.6436 $\left.{ }^{\circ} \mathrm{N}, 120.9607^{\circ} \mathrm{E}\right)$, coll. DRA Dela Cruz, GAA Viernes, JF Wong, ESP Dela Paz and ML Lopez, June 2016 (UST-ZRC 0178, 1 spec.). Tullahan River $\left(14.6705^{\circ} \mathrm{N}, 120.9584^{\circ} \mathrm{E}\right)$, coll. DRA Dela Cruz, GAA Viernes, JF Wong, ESP Dela Paz and ML Lopez, June 2016 (UST-ZRC 0179A-B, 1 spec.). Veterans Memorial Medical Center lagoon $\left(14.6571^{\circ} \mathrm{N}\right.$, 121.0380 E), coll. DRA Dela Cruz, GAA Viernes, JF Wong, ESP Dela Paz and ML Lopez, June 2016 (USTZRC 018, 1 spec.).

Short description. This species is relatively larger than the 2 Thermocyclops observed in this study. The body is generally large at the prosome and narrows to the urosome. The lateral arms of the seminal receptacle are long and broad and are curved posteriorly; the anterior margin has wave-like indentations at the proximal; Transverse duct-like structure forms a "V" shape. This species is highly recognized by the several hairs present at the entire median length of the caudal rami. The medial apical spine of the P4 endopodite is longer than the lateral, with spinules present at the entire anterior surface of 1 side and few spinules at the medial surface of the other side. All the morphological characters concur with the description of Hołyńska (2003) and Dela Paz et al. (2016a).

Ecological distribution. Mesocyclops aspericornis is found in wide variety of habitats including lakes, ponds, swamps, and rice fields (Lopez et al. 2017). This species has a great dispersal capability but adequate in competitive abilities.

\section{Thermocyclops decipiens (Kiefer, 1929)}

Materials examined. Philippines: Luzon: Manila: UST Botanical Garden pond $\left(14.6101^{\circ} \mathrm{N}, 120.9885^{\circ} \mathrm{E}\right)$, coll. DRA Dela Cruz, GAA Viernes, JF Wong, ESP Dela Paz and ML Lopez, June 2016 (UST-ZRC 0188-0189, 2 spec.). La Mesa Ecopark Pond $\left(14.7113^{\circ} \mathrm{N}, 121.0756^{\circ}\right.$ E), coll. DRA Dela Cruz, GAA Viernes, JF Wong, ESP Dela Paz and ML Lopez, June 2016 (UST-ZRC 0182AB, 0183-0184, 3 spec.). La Mesa Ecopark Lagoon $\left(14.7121^{\circ} \mathrm{N}, 121.0756^{\circ} \mathrm{E}\right)$, coll. DRA Dela Cruz, GAA Viernes, JF Wong, ESP Dela Paz and ML Lopez, June 2016 (UST-ZRC 0185-0186, 2 spec.). Creek in Muñoz $\left(14.6574^{\circ} \mathrm{N}, 121.0157^{\circ} \mathrm{E}\right)$, coll. DRA Dela Cruz, GAA Viernes, JF Wong, ESP Dela Paz and ML Lopez, June 2016 (UST-ZRC 0187A-B, 1 spec.). Veterans Memorial Medical Center lagoon $\left(14.6571^{\circ} \mathrm{N}, 121.0380^{\circ} \mathrm{E}\right)$, coll. 
DRA Dela Cruz, GAA Viernes, JF Wong, ESP Dela Paz and ML Lopez, June 2016 (UST-ZRC 0190, 1 spec.).

Short description. The body is generally large at the prosome and narrows to the urosome. The arms of the seminal receptacle are wide and straight. The caudal rami are smooth and naked. The marginal extension at the P4 basipodite bears few spinules. The distal margin at $\mathrm{P} 4$ intercoxal sclerite is high and triangular in shape. The apical medial spine of P4 endopodite is $2-2.7$ times longer than the lateral spine. All the morphological characters concur with the description of Mirabdullayev (2003) and Dela Paz et al. (2016a).

Ecological distribution. Thermocyclops decipiens is found in large variety of freshwater habitats including lakes, rivers, ponds, reservoirs, swamps, and falls. This species inhabits the freshwater, also survive in relatively saline or eutrophic condition.

\section{Thermocyclops taihokuensis (Harada, 1931)}

Materials examined. Philippines: Luzon: Manila: creek in Muñoz $\left(14.6574^{\circ} \mathrm{N}, 121.0157^{\circ} \mathrm{E}\right)$, coll. DRA Dela Cruz, GAA Viernes, JF Wong, ESP Dela Paz and ML Lopez, June 2016 (UST-ZRC 0200A, 1 spec.). Kalayaan Creek $\left(14.6900^{\circ} \mathrm{N}, 120.9366^{\circ} \mathrm{E}\right.$ and $14.6904^{\circ} \mathrm{N}$, $\left.120.9365^{\circ} \mathrm{E}\right)$, coll. DRA Dela Cruz, GAA Viernes, JF Wong, ESP Dela Paz and ML Lopez, June 2016 (USTZRC 0191A-B, 0192, 2 spec.). La Mesa Ecopark pond $\left(14.7113^{\circ} \mathrm{N}, 121.0756^{\circ} \mathrm{E}\right)$, coll. DRA Dela Cruz, GAA Viernes, JF Wong, ESP Dela Paz and ML Lopez, June 2016 (UST-ZRC 0194A-B, 0195A-B, 0196A-B, 0197A-B, 0198-0199, 6 spec.). Pasig River (14.5946 N, $121.0125^{\circ}$ E), coll. DRA Dela Cruz, GAA Viernes, JF Wong, ESP Dela Paz and ML Lopez, June 2016 (UST-ZRC 0200B, 1 spec.). Veterans Memorial Medical Center lagoon $\left(14.6571^{\circ} \mathrm{N}, 121.0380^{\circ} \mathrm{E}\right)$, coll. DRA Dela Cruz, GAA Viernes, JF Wong, ESP Dela Paz and ML Lopez, June 2016 (UST-ZRC 0201, 0203, 2 spec.). Creek in Tomas Morato Avenue beside Creekside Square $\left(14.6260^{\circ} \mathrm{N}, 121.0334^{\circ} \mathrm{E}\right)$, coll. DRA Dela Cruz, GAA Viernes, JF Wong, ESP Dela Paz and ML Lopez, June 2016 (UST-ZRC 0202, 1 spec.). La Mesa Ecopark Pond $\left(14.7113^{\circ} \mathrm{N}, 121.0756^{\circ} \mathrm{E}\right)$, coll. DRA Dela Cruz, GAA Viernes, JF Wong, ESP Dela Paz and ML Lopez, June 2016 (UST-ZRC 0193, 1 spec.).

Short description. The body is generally large at the prosome and narrows to the urosome. The arms of the seminal receptacle are curved posteriorly. Caudal rami are diverging and naked. The marginal extension at the P4 basipodite bears few spinules. The distal margin at the P4 intercoxal sclerite is protuberant bearing small spinules. The medial apical spine of P4 endopodite is almost 3 times longer than the lateral spine. All the morphological characteristics concur with the descriptions and illustrations of Mirabdullayev (2003) and Dela Paz et al. (2016a).
Ecological distribution. Thermocyclops taihokuensis is found mostly in lakes, small pool, fish ponds, and rice fields. This species can survive and tolerate eutrophic condition.

Order Calanoida Sars, 1903

Family Diaptomidae Baird, 1850

\section{Arctodiaptomus dorsalis (Marsh, 1907)}

Materials examined. Philippines: Luzon: Manila: Pasig River $\left(14.5604^{\circ} \mathrm{N}, 121.0659^{\circ} \mathrm{E}\right)$, coll. DRA Dela Cruz, GAA Viernes, JF Wong, ESP Dela Paz and ML Lopez, June 2016 (UST-ZRC 0253A-B, USTZRC 0254, USTZRC 0255A-B, and USTZRC 0256A-B, 4 spec.).

Short description. The body is generally elongated with a long antennule that generally reaches the tip of the urosome. Male specimen: antennule is geniculated. Right exopodite 2 of P5 leg is relatively large and bears a long, thin, and strongly curved terminal claw on the posteromedian area; and with a short lateral spine protruding near the middle of exopodite 2. Female specimen: antennule is straight. The pair of P5 is symmetrical. All the morphological characteristics concur with the descriptions and illustrations of Dussart and Defaye (2001) and Papa et al. (2012).

Ecological distribution. Arctodiaptomus dorsalis is found in lakes and rivers. This species is an invasive copepod hence that can tolerate eutrophic condition (Papa et al. 2012).

\section{Filipinodiaptomus insulanus (Wright, 1927)}

Materials examined. Philippines: Luzon: Manila: Ninoy Aquino Parks \& Wildlife Lagoon $\left(14.6512^{\circ} \mathrm{N}, 121.0432^{\circ}\right.$ $\mathrm{E}$ and $14.6507^{\circ} \mathrm{N}, 121.0432^{\circ} \mathrm{E}$ ), coll. DRA Dela Cruz, GAA Viernes, JF Wong, ESP Dela Paz and ML Lopez, June 2016 (UST-ZRC 0258A-B, 1 spec.). Veterans Memorial Medical Center $\left(14.6571^{\circ} \mathrm{N}, 121.0380^{\circ} \mathrm{E}\right)$, coll. DRA Dela Cruz, GAA Viernes, JF Wong, ESP Dela Paz and ML Lopez, June 2016 (UST-ZRC 0259A-B, 0260A-B, and 0261A-B, 3 spec.). La Mesa Dam $\left(14.7168^{\circ} \mathrm{N}, 121.0731^{\circ} \mathrm{E}\right)$, coll. DRA Dela Cruz, GAA Viernes, JF Wong, ESP Dela Paz and ML Lopez, June 2016 (UST-ZRC 0257A-B, 1 spec.).

Short description. The body is generally elongated with a long antennule that generally reaches the tip of the urosome. Male: the antennule is geniculated; the antepenultimate segment of the right antennule bears an antepenultimate process which contains 5-8 teeth on the outer margin. The right exopodite 2 of P5 is larger and longer than the left, and has a long, broad, and slightly curved terminal claw on the postero-median area; and with a short lateral spine protruding from the exopodite 2. Female: the antennule is straight. The pair of P5 leg is symmetrical. All the morphological characters concur with the species descriptions of Lai and Fernando (1980). 
Ecological distribution. Filipinodiaptomus insulanus was found in lakes, reservoirs, and golf course lagoons. This is a Philippine-endemic calanoid copepod (Lai and Fernando 1980, Mamaril 1986).

\section{Discussion}

Among the cladocerans, members of the family Sididae including Diaphanosoma dubium, D. excisum, D. sarsi, were the most frequently encountered species from the collected samples, followed by moinids and daphniids such as Moina micrura, Moinodaphnia macleayi, and Ceriodaphnia cornuta. In contrast, Bosmina fatalis and Chydorus cf. sphaericus were rarely encountered in the samples, occurring only at three localities with the latter found in only 1 locality (Table 1). Chydorus cf. sphaericus is a known cosmopolitan species (Maiphae et al. 2008), which is tolerant to variable physico-chemical water characters, thus making it good bio-indicator. It mostly occurs in the littoral area with macrophyte stands. As such, the rarity of this animal in our collection may also be due to the absence of macrophytes during the sampling and the lack of collections benthic habitats. The 8 species of Cladocera identified in our study were already known to be present in Metropolitan Manila from surveys conducted between the 1950s and 1970s (Cheng and Clemente 1954, Mamaril 1978) from La Mesa reservoir, as well as the Pasig and Marikina rivers. However, there are new locality records for $C$. cornuta and $D$. dubium in Pasig River (Table 1). The species composition and distribution of these species agrees with the previous observation of Fernando (1980a, b) on the distributional patterns of Diaphanosoma in comparison with other cladoceran taxa as well as the absence of Daphnia in the tropics. So far, the genus Daphnia are restricted to temperate and subtropical regions. The old record of the Daphnia pulex in the Philippines (Wright 1928) is suspicious and need validation (Petersen and Carlos 1984, Mamaril 2001). Our current efforts in sampling Cladocera from various localities throughout the Philippines has not yielded any Daphnia so far (Cheng and Clemente 1954, Mamaril 2001, Pascual et al. 2014, Dela Paz et al. 2016b).

We collected copepod samples from small (ponds and canals) to large water bodies including Pasig River and La Mesa reservoirs (Table A1, Appendix) during the wet season. We were able to identify Mesocyclops aspericornis, Thermocyclops decipiens and T. taihokuensis from various localities (Table 1) together with 2 species of calanoid copepods, Arctodiaptomus dorsalis and Filipinodiaptomus insulanus (Table 1).

Previously recorded copepods in Metropolitan Manila include A. dorsalis (Pasig River) (Papa et al. 2012), F. insulanus (La Mesa Reservoir) (Mamaril 1986) and T. philippinesis (Manila) (Marsh 1932). Arctodiaptomus dorsalis and F. insulanus were still collected from various sites in Manila. However, the endemic T. philippinensis has not been identified from any of our collected samples. As such, no new occurrence of T. philippinen- sis has been found since the study of Marsh (1932). All identified cyclopoid copepods in this study, including $M$. aspericornis, T. decipiens and T. taihokuensis are new locality records for 15 sites (Table 1). These species are commonly collected from different freshwater habitats in other parts of the country (Papa and Hołyńska 2013, Dela Paz et al. 2016b). The distribution of the fugacious $M$. aspericornis in the Philippines was previously limited to 1 record each on the islands of Luzon (Tuyor and Baay 2001), 1 in Camiguin (Hołyńska 2000), and 1 in Cebu (Dela Paz et al. 2016a). Hence, the occurrence of $M$. aspericornis in Metropolitan Manila contributes to the better understanding of its species distribution in the Philippines by providing new insights on its possible pattern of dispersal in the country and the entire Southeast Asian region (Table 1). The Philippine record of $T$. decipiens ranges from northern to southern Philippines including major islands such as Luzon, Panay, Negros, Cebu, Bohol, and Mindanao (Papa and Hołyńska 2013, Dela Paz et al. 2016a, b). This species was found in a wide range of freshwater habitats including lakes, fishponds, dams, and waterfalls from previous study done by several researchers (Dela Paz et al. 2016a, Lopez et al., 2017).

On the other hand, T. taihokuensis was previously recorded from the northern and southern parts of Luzon (Papa and Hołyńska 2013, Dela Paz and Papa 2018), in eastern Visayas (Dela Paz et al. 2016a), and southern Mindanao (Dela Paz et al. 2016b). This cyclopoid is commonly observed in lakes and fishponds. Hence, we suspect that aquaculture and co-introduction of planktivorous fishes which harbor zooplankton are the possible causes of introduction of this species in Philippine freshwaters. The occurrence of T. taihokuensis in a highly urbanized area such as Metropolitan Manila where freshwaters have high nutrient levels seemed to support the idea that $T$. taihokuensis can disperse and maintain its population in a eutrophic environment. As such, this species can be used for biomonitoring. A few studies of the plateau lakes in China revealed that the great biomass of copepods (including T. taihokuensis which contributed more on the total biomass because of its relatively high density) is positively correlated with the high level of Chlorophyll a (Wang et al. 2007, Guo et al. 2009). As an omnivorous animal, T. taihokuensis consume blue-green algae which most other copepods cannot exploit; this helps maintain high populations in mesotrophic or eutrophic water conditions (Reid 1989, Chang and Hanazato 2004). Moreover, high biomass of algal bloom-forming phytoplankton species would cause a decrease on the amount of dissolved oxygen which provides a potential refuge of $T$. taihokuensis against planktivorous fishes (Chang and Hanazato 2004). Also, it had been observed that $T$. taihokuensis was one of the most common components of the plankton community during summer and this animal was found in lesser numbers or totally absent during winter in subtropical freshwaters (Wang et al. 2007, Guo et al. 2009). In the Philippine, T. taihokuensis 
has been found in ponds and lakes on Leyte Island and South Cotabato during wet and dry seasons (Dela Paz et al. 2016a, b) which points to the fact that this species occurs throughout the year in the tropics. As such, T. taihokuensis may indeed be considered as a thermophilic cyclopoid (Wang et al. 2007) given its predominance in tropical freshwaters.

The invasive calanoid copepod A. dorsalis was originally recorded from Americas and subsequently introduced in the Philippines through the release of drinking water reserves of transcontinental ships, as well as through the aquarium trade (Papa et al. 2012). The first record of this species in the Philippines was in Laguna de Bay (Luzon Island) (Papa et al. 2012). Current efforts to determine the distribution of $A$. dorsalis in the Philippines revealed that this species occurs in several lakes on Luzon and Mindanao (Tuyor and Baay 2001, Papa et al. 2012, Rizo et al. 2015, Dela Paz et al. 2016b). Our results revealed that $A$. dorsalis is not widely distributed in Metropolitan Manila except for Pasig River, which is the sole outlet of Laguna de Bay. On the other hand, the endemic $F$. insulanus was first collected in Manila (exact location not mentioned in the paper) (Wright 1928) and has thereafter been recorded from Laguna de Bay and La Mesa reservoir (Petersen and Carlos 1984, Mamaril 1986, Mamaril 2001), Lake Paoay (Aquino et al. 2008, Papa et al. 2012), Pantabangan Dam reservoir (Lopez et al. 2017) and Lake Danao in Leyte (Tuyor and Baay 2001) has been collected in a golf course lagoon and again from the La Mesa reservoirs in Quezon City (Table 1). The record in Lake Danao is a possible misidentification, since as previous records from Brehm (1933) revealed the presence of Diaptomus vexillifer in the lake. This was further validated in more recent studies as reported by Lopez et al. (2017). Filipinodiaptomus insulanus seems to be present only in less-disturbed habitats with low fish densities. Our results also confirmed the northern distributional range of $F$. insulanus in the Philippines.

Information on the occurrences of the Cladocera and Copepoda on the freshwater habitats in Metropolitan Manila helps us to better understand the ability of these animals to tolerate and maintain a population in the wastewater and contaminated water in urban areas. In comparison, the cladocerans C. cornuta, D. sarsi, $M$. micrura and the copepod T. taihokuensis were similarly found in urban ponds and wetlands in Turkey and southern China (Liu et al. 2016, Adhikari et al. 2017). Such observations have confirmed that these microcrustaceans can be regarded as "urban zooplankton", which may be useful indicators for assessing water quality.

Despite the poor water quality in most areas in Metropolitan Manila, our results show that 13 species of freshwater microcrustaceans are present at our 23 sampling localities. The presence of these species in highly urbanized areas like Metropolitan Manila points out capacity of these species to thrive in eutrophic, highly polluted, and disturbed aquatic environments. Though this study does not put emphasis on the relationship between the distribution and abundance of the collected specimens and the prevailing environmental conditions in the different sampling sites, the results still serve as an important update on the species composition of microcrustaceans in the highly urbanized area of Metropolitan Manila, where little or no attention has been given to studying freshwater biodiversity and conservation. Interestingly, all the cladocerans and copepods identified from Metropolitan Manila were already observed from other freshwater ecosystems in the Philippines (Dela Paz et al. 2016b). However, our current result revealed distinct patterns in terms of microhabitat choice by these microcrustacean zooplankton species in an urban environment. Given the low number of studies conducted on urban biodiversity and ecology, and the limited taxa covered by these studies (Vallejo et al. 2009) in Metropolitan Manila, our results serve as an important contribution to our current knowledge of aquatic biodiversity in Metropolitan Manila, one of the most densely populated urban centers in the planet.

\section{Acknowledgements}

We thank the Research Center of Natural and Applied Sciences of the University of Santo Tomas, which provided facilities for this study. RDS Papa was supported by a research grant from the Research Center for the Natural and Applied Sciences, UST while MLD Lopez and ESP Dela Paz were supported by the Tonolli Fund of the International Society of Limnology (SIL).

\section{Authors' Contributions}

RDSP conceptualized the study design and provided materials for the fieldwork. CIHD, DRDC, GAV and JFW collected the water samples and processed the samples in the laboratory including sorting, identification, preparing of voucher specimens and wrote the first version of the manuscript. MLL and ESPDP helped in the sample collection and identification of the specimens. ESPDP, MLL and RDSP did the analysis and wrote the final version of the manuscript.

\section{References}

Adhikari S, Roy Goswami A, Mukhopadhyay SK. 2017. Diversity of zooplankton in municipal wastewater-contaminated urban pond ecosystems of the lower Gangetic plains. Turkish Journal of Zoology, 41: 464-475. https://doi.org/10.3906/zoo-1601-12

Aquino MRY, Cho CD, Cruz MAS, Saguiguit MAG, Papa RDS (2008) Zooplankton compostion and diversity in Paoay Lake, Luzon Is., Philippines. Philippine Journal of Science 137: 169-177.

Berner DB (1985) Morphological differentiation among species in the Ceriodaphnia cornuta complex (Crustacea, Cladocera). Verhandlungen des Internationalen Verein Limnologie 22: 3099-3103.

Boxshall GA, Halsey SH (2004) An introduction to Copepod Diversity. Henry Ling, The Dorset Press, Dorshester, 503-507.

Brehm V (1938) Die Cladoceren der Wallacea-Expedition. Internationale Revue der gesamten Hydrobiologie und Hydrographie 38: 99-124. Brehm V (1942) Uber die diaptomiden und pseudodiaptomiden der 
zwischenregion Wallacea. Internationale Revue der Gesamten Hydrobiologie und Hydrographie 42: 264-287.

Cavite YG, Juan J, Koh MI, Lopez ML, and Papa RDS (2017) Species composition of freshwater zooplankton fauna from selected groundwater-dependent ecosystems in Bulacan Province (Philippines) with taxonomic notes on new locality record of harpacticoid species in the Philippines. Philippine Journal of Systematic Biology 11 (1): 45-47.

Chang KH, Hanazato T (2004) Diel vertical migrations of invertebrate predators (Leptodora kindtii, Thermocyclops taihokuensis, and Mesocyclops sp.) in a shallow, eutrophic lake. Hydrobiologia 528: 249-259. https://doi.org/10.1007/s10750-004-3952-x

Cheng T, Clemente L (1954) The classification and distribution of freshwater cladocerans around Manila (Doctoral dissertation). University of the Philippines, Quezon City.

Dela Paz ESP, Hołyńska MK, Papa RDS (2016a) Mesocyclops and Thermocyclops (Copepoda, Cyclopidae) in the major Visayas Islands (Central Philippines). Crustaceana 89: 787-809. https://doi. org/10.1163/15685403-00003547

Dela Paz ESP, De Leon GO, Fernandez AB, Tan CAF, Manuel, II AL, Villalon JVR, Zamora CVL, Papa RDS (2016b) Faunistic survey of the Philippine Freshwater microcrustacean zooplankton: new locality records and updated species accounts. Philippine Journal of Systematic Biology 10: 48.

Dela Paz ESP, Papa RDS (2018) New locality records for Mesocyclops Sars, 1914 and Thermocyclops Kiefer, 1927 in Luzon and Mindanao islands in the University of Santo Tomas - Zooplankton Reference Collection (UST-ZRC). Philippine Science Letters 11(1): 3-9.

Dumont H, Negrea S (2002) Introduction to the Class Branchiopoda. Backhuys Publishers, Leiden, 389 pp.

Dussart BH, Defaye D (2001) Introduction to the Copepoda. 2nd edition. Guide to the Identification of the Microinvertebrates of the Continental Waters of the World, No. 16. Backhuys Publishers, Leiden. 344 pp.

Dussart BH, Fernando CH, Matsumura-Tundisi, Shiel RJ (1984) A review of systematics, distribution and ecology of tropical freshwater zooplankton. Hydrobiologia 113: 77-91.

Fernando CH (1980a) The freshwater zooplankton of Sri Lanka with a discussion of tropical freshwater zooplankton. Internationale Revue der gesamten Hydrobiogie 65: 85-125.

Fernando CH (1980b) The species and size composition of tropical freshwater zooplankton with special reference to the Oriental Region (South East Asia). Internationale Revue der gesamten Hydrobiogie, 65: 411-426.

Fernando CH (2002) A Guide to Tropical Freshwater ZooplanktonIdentification, Ecology and Impact on Fisheries. Backhuys Publishers, Leiden, 291.

Fryer G (1968) Evolution and adaptive radiation in the Chydoridae (Crustacea: Cladocera): a study in comparative functional morphology and ecology. Philosophical Transactions of the Royal Society of London, Series B, Biological Sciences 254: 221-384. https://doi.org/10.1098/rstb.1968.0017

Goulden CE (1968) The systematics and evolution of the Moinidae. Transaction of the American Philosophical Society (New Series) 58 (6) $1-101$

Guo N, Zhang M, Yu Y, Qian S, Li D, Kong F (2009) Crustacean zooplankton communities in 13 lakes of Yunnan-Guizhou plateau: Relationship between crustacean zooplankton biomass or size structure and trophic indicators after invasion by exotic fish. Annales de Limnologie, International Journal of Limnology 45: 279-288. https://doi.org/10.1051/limn/2009022

Hołyńska M (2000) Revision of the Australasian species of the genus Mesocyclops Sars, 1914 (Copepoda: Cyclopidae). Annales Zoologici 50: 363-447.

Kiefer F (1930) Süsswasser-Copepoden (Calanoida und Cyclopoida) von der insel Luzon, Philippinen. Philippine Journal of Science, 41: 151-157.

Kiefer F (1938) Die von der Wallacea-Expedition gesammelten Arten der Gattung Thermocyclops Kiefer. Internationale Revue der Gesamten Hydrobiologie und Hydrographie 38: 54-74.

Korovchinsky NM (1992) Sididae and Holopidae (Crustacea: Daphniformes). Guides to the Identification of the Microinvertebrates of the Continental Waters of the World. 3. SPB Publishing, The Hague, 82.

Korovchinsky NM (2002) Description of two new species of Diaphanosoma Fischer, 1850 (Crustacea, Branchiopoda, Sididae) from the United States and Canada and species richness of the genus in North America. Hydrobiologia 489: 45-54.

Lai HC, Fernando CH (1980) Zoogeographical distribution of Southeast Asian Freshwater Calanoida. Hydrobiologia 74: 53-66. https:// doi.org/10.1007/bf00009015

Liu S, Shi X, Xu H, Liu G, Hou C, Zhu X (2016) Seasonal shift in zooplankton communities in two sub-tropical urban wetlands, Southern China. Acta Ecologica Sinica 36: 236-245. https://doi. org/10.1016/j.chnaes.2016.03.006

Lopez MLD, Pascual JAF, Dela Paz ESP, Rizo EZC, Tordesillas D, Guinto SK, Han B, Dumont HJ, Mamaril AC, and Papa RDS (2017a) Annotated checklist and insular distribution of freshwater microcrustaceans (Copepoda: Calanoida \& Cyclopoida; Cladocera: Anomopoda \& Ctenopoda) in the Philippines. The Raffles Bulletin of Zoology 65: 623-654.

Lopez MLD, Magbanua FS, Mamaril AC, Papa RDS (2017b) Variations in microcrustacean (Crustacea: Cladocera, Copepoda) assemblages from selected groundwater-dependent ecosystems in the greater Luzon and Mindoro Island faunal regions (Philippines): insights to tropical groundwater ecology. Inland Waters 7 (4): 428-439. https://doi.org/10.1080/20442041.2017.1368597

Maiphae S, Pholpunthin, P, Dumont HC (2008) Taxon richness and biogeography of the Cladocera (Crustacea: Ctenopoda, Anomopoda) of Thailand. Annales de Limnologie, International Journal of Limnology 44 (1): 33-43. https://doi.org/10.1051/ limn:2008021

Mamaril AC (1986) Zoooplankton (Vol. VII). In: Guide to Philippine flora and fauna. Natural Resources Management Center and University of the Philippines Diliman, Quezon City, 268.

Mamaril AC (2001) Zooplankton diversity in Philippine lakes. In: Conservation and Ecological Management of Philippine Lakes in Relation to Fisheries and Aquaculture. Southeast Asian Fisheries Development Center, Aquaculture Department, Philippine Council for Aquatic Aquatic and Marine Research and Development, Bureau of Fisheries and Aquatic Resources, Quezon City, 81-93.

Mamaril AC, Fernando CH (1978) Freshwater zooplankton of the Philippines (Rotifera, Cladocera and Copepoda). Natural and Applied Science Bulletin 30: 109-221.

Manasan RG, Mercado RG (1999) Governance and urban development: case study of metro Manila. Philippine Institute for Development Studies Discussion Series 99-03. Philippine Institute for Development Studies, Makati, Philippines, 1-29.

Marsh C D (1932) A new species of Cyclops from the Philippine islands. Journal of the Washington Academy of Sciences 22: 182-184.

Metillo EB, Masorong AM, Macabangkit SAN, Licayan JRU, Tordesillas DT, Papa RDS (2014) First record of the invasive Arctodiaptomus dorsalis (Marsh, 1907) (Copepoda: Calanoida: Diaptomidae) in Lake Lanao (Mindanao Is., Philippines). Acta Manilana 62: 19-23.

Orozco GP, Zafaralla MT (2012) Biophysico-chemical and socioeconomic study of two major Manila esteros. Biology Education for Social and Sustainable Development, 161-171. https://doi. org/10.1007/978-94-6091-927-5_17

Papa RDS, Li H, Tordesillas DT, Han B, Dumont HJ (2012) Massive Invasion of Arctodiaptomus dorsalis (Copepoda, Calanoida, Diaptomidae) in Philippine lakes; a threat to Asian zooplankton biodiversity? Biological Invasions 14 (12): 2471-2478. http://doi. org/10.1007/s10530-012-0250-9

Papa RDS, Hołyńska MK (2013) An overview of the limnetic Cyclopidae (Crustacea, Copepoda) of the Philippines, with emphasis on 
Mesocyclops. Journal of Limnology 72: 290-312. https://doi org/10.4081/jlimnol.2013.s2.e14

Parmar TK, Rawtani D, Agrawal YK (2016) Bioindicators: the natural indicator of environmental pollution. Frontiers in Life Science 9(2): 110-118. https://doi.org/10.1080/21553769.2016.1162753

Pascual JAF, Rizo EZC, Han B, Dumont HJ, Papa RDS (2014) Taxonomy and distribution of four Cladoceran families (Branchiopoda: Cladocera: Moinidae, Bosminidae, Chydoridae and Sididae) in Philippine inland waters. Raffles Bulletin of Zoology 62: 771-794.

Petersen F, Carlos M (1984) A review of zooplankton in Philippine lakes. Fisheries Research Journal of the Philippines 9: 56-64.

Qian X, Capistrano ET, Lee W, Ishikawa T, Yokoyama K, Shoji K (2000) Field survey on the flow structure and water quality of Pasig River in metro Manila. Annual Journal of Hydraulic Engineering, JSCE 44 (2): 1101-1106. https://doi.org/10.2208/prohe.44.1101

Reid JW (1989) The distribution of the genus Thermocylops (Copepoda, Cyclopoida) in the western hemisphere, with description of T. parvus, new species. Hydrobiologia 175: 149-174. https://doi. org $/ 10.1007 / \mathrm{bf00765125}$

Rizo EZC, Pascual JAF, Dy DJB, Labicane LJA, Trinidad CB, Papa RDS (2015) New records of an invasive calanoid copepod, Arctodiaptomus dorsalis (Marsh, 1907) in freshwater ecosystems in the Bicol Peninsula (Luzon Is., Philippines). International Journal of Philippine Science and Technology 1:27-30.

Rizo EZC, Gu Y, Papa RDS, Dumont HJ, Han B (2017) Identifying functional groups and ecological roles of tropical ad subtropical freshwater Cladocera in Asia. Hydrobiologia 799 (1): 83-99. https//doi.org/10.1007/s10750-017-3199-y

Rola AC, Pulhin JM, Tabios, III GQ, Lizada JC, Dayo MHF (2015) Challenges of Water governance in the Philippines. Philippine Journal of Science 144 (2): 197-208.

Smirnov NN (1996) Cladocera: The Chydoridae and Sayciinae (Chydoridae) of the World. SPB Publishing, The Hague, 183

Tordesillas DT, Abaya NKP, Dayo MAS, Marquez LEB, Papa RDS,
Ban S (2016) Effect of temperature on life history traits of the invasive calanoid copepod Arctodiaptomus dorsalis (Marsh, 1907) from Lake Taal, Philippines. Plankton Benthos 11 (4): 105-111. https://doi.org/10.3800/pbr.11.105

Tuyor JB, MO Baay (2001) Contribution to the knowledge of the freshwater Copepoda of the Philippines. Asia Life Sciences 10: 35-43.

Uéno M (1966) Freshwater zooplankton of Southeast Asia. The Southeast Asian Studies 3: 94-105.

Vallar E, Oliveros J, Galvez MC, Bagtasa G (2015) Effect of the Urbanization of Metro Manila on the Climate of Selected Urban and Rural Areas using WRFV3.4.1. DeLa Salle University, Manila, 1-6.

Vallejo Jr. BM, Aloy AB, Ong PS (2009) The distribution, abundance and diversity of birds in Manila's last greenspaces. Landscape and Urban Planning 89: 75-85. https://doi.org/10.1016/j.landurbplan.2008.10.013

Varpe O, Jorgensen C, Tarling GA, Fiksen O (2007) Early is better: seasonal egg fitness and timing of reproduction in a zooplankton life-history model. Oikos 116: 1331-1342. https://doi.org/10.1111/ j.2007.0030-1299.15893.x

Wang S, Xie P, Wu S, Wu A (2007) Crustacean zooplankton distribution patterns and their biomass as related to trophic indicators of 29 shallow subtropical lakes. Limnologica 37: 242-249. https://doi. org/10.1016/jlimno.2007.02.002

Woltereck R, Tressler WS, Bunag DM (1941) Die Seen und Inseln der «Wallacea»-Zwishenregion und ihre endemische Tierwelt. Zweiter Teil: Inseln und Seen der Philippinen. Internationale Revue der gesamten Hydrobiologie und Hydrographie 41: 37-176.

Wright S (1928) A new species of Diaptomus from the Philippine Islands. Transactions of the Wisconsin Academy Sciences 23: 583-585.

Zoleta DB (2000) Flood hazards in Metro Manila: Recognizing commonalities, differences, and courses of action. Social Science Diliman 1 (1): 60-105. 


\section{Appendix}

Table A1. Geographical coordination and environmental characters of the selected sampling sites in Metropolitan Manila.

\begin{tabular}{|c|c|c|c|c|c|c|c|c|c|}
\hline No. & Sampling locality & $\begin{array}{c}\text { No. of } \\
\text { sites }\end{array}$ & $\begin{array}{c}\text { DO } \\
\text { (mg/L) }\end{array}$ & $\begin{array}{c}\text { Temp. } \\
\left({ }^{\circ} \mathrm{C}\right)\end{array}$ & pH & $\begin{array}{c}\text { Conductivity } \\
(\mu \mathrm{s} / \mathrm{cm})\end{array}$ & $\begin{array}{l}\text { Latitude } \\
\quad\left({ }^{\circ} \mathrm{N}\right)\end{array}$ & $\begin{array}{l}\text { Longitude } \\
\left({ }^{\circ} \mathrm{E}\right)\end{array}$ & Description \\
\hline 1 & Kalayaan Creek & 2 & $\begin{array}{l}1.07 \\
1.44\end{array}$ & $\begin{array}{l}30.9 \\
31.5\end{array}$ & $\begin{array}{c}7.5 \\
12.53\end{array}$ & 4502955211 & $\begin{array}{l}14.6900 \\
14.6904\end{array}$ & $\begin{array}{l}120.9366 \\
120.9365\end{array}$ & $\begin{array}{l}\text { Near residential areas } \\
\text { With fish pens }\end{array}$ \\
\hline 2 & Gov. Pascual Ave. estero & 1 & 0.4 & 28.8 & 5.95 & 872 & 14.6706 & 120.9508 & Near residential areas \\
\hline 3 & Tullahan River & 2 & $\begin{array}{l}33.2 \\
2.34\end{array}$ & $\begin{array}{c}28.49 \\
33.8\end{array}$ & $\begin{array}{l}4.15 \\
6.86\end{array}$ & 89452816 & $\begin{array}{l}14.6708 \\
14.6705\end{array}$ & $\begin{array}{l}120.5925 \\
120.9584\end{array}$ & $\begin{array}{l}\text { Near residential areas } \\
\text { Near dump site }\end{array}$ \\
\hline 4 & Navotas River & 1 & 2.21 & 32.5 & 6.74 & NR & 14.6436 & 120.9607 & Minimal vegetation \\
\hline 5 & Estero de Maypajo & 1 & 0.26 & 29.6 & 8.6 & 2346 & 14.6353 & 120.9752 & Near residential areas \\
\hline 6 & Estero de la Reina & 2 & $\begin{array}{l}N R \\
3.64\end{array}$ & $\begin{array}{l}28.8 \\
24.7\end{array}$ & $\begin{array}{l}7.18 \\
8.44\end{array}$ & 16631136 & $\begin{array}{l}14.6092 \\
14.6011\end{array}$ & $\begin{array}{l}120.9721 \\
120.9763\end{array}$ & $\begin{array}{l}\text { Near residential areas } \\
\text { Near commercial } \\
\text { establishments }\end{array}$ \\
\hline 7 & Pasig River & 4 & $\begin{array}{l}3.11 \\
2.71 \\
2.45 \\
\text { NR }\end{array}$ & $\begin{array}{c}25.1 \\
24.9 \\
30.5 \\
\text { NR }\end{array}$ & $\begin{array}{c}8.76 \\
9.6 \\
7.17 \\
N R\end{array}$ & $\begin{array}{l}10001000 \\
1684 \mathrm{NR}\end{array}$ & $\begin{array}{l}14.5963 \\
14.5959 \\
14.5946 \\
14.5604\end{array}$ & $\begin{array}{l}120.9774 \\
120.9771 \\
121.0125 \\
121.0659\end{array}$ & $\begin{array}{l}\text { Near residentials and } \\
\text { Commercial establishments }\end{array}$ \\
\hline 8 & UST Botanical Garden Pond & 1 & 0.18 & 27.3 & 9.71 & 722 & 14.6101 & 120.9885 & Man-made pond \\
\hline 9 & Estero de Pandacan & 1 & 0.28 & 30.9 & 7.55 & 731 & 14.5906 & 121.0020 & Near residential areas \\
\hline 10 & Estero de San Miguel & 1 & 2.5 & 24.3 & 9.04 & 964 & 14.6006 & 120.9854 & Near residential areas \\
\hline 11 & San Juan River & 2 & $\begin{array}{l}3.46 \\
0.69\end{array}$ & $\begin{array}{c}29.3 \\
30\end{array}$ & 7.217 & 841875 & $\begin{array}{l}14.5939 \\
14.6088\end{array}$ & $\begin{array}{l}121.0261 \\
121.0220\end{array}$ & Near residential areas \\
\hline 12 & Creek in Tomas Morato Ave. & 1 & 4.2 & 29.9 & 6.99 & 575 & 14.6260 & 121.0334 & Beside creekside square \\
\hline 13 & $\begin{array}{l}\text { Ninoy Aquino Parks and Wildlife } \\
\text { Center lagoon }\end{array}$ & 2 & 3.93 & 21.7 & 6.9 & 297 & $\begin{array}{l}14.6512 \\
14.6507\end{array}$ & $\begin{array}{l}121.0432 \\
121.0432\end{array}$ & Near vegetation \\
\hline 14 & $\begin{array}{l}\text { Veterans Memorial Medical } \\
\text { Center lagoon } 1\end{array}$ & 1 & 0.45 & 28.9 & 7.28 & 601 & 14.6535 & 121.0424 & Minimal vegetation \\
\hline 15 & $\begin{array}{l}\text { Veterans Memorial Medical } \\
\text { Center lagoon } 2\end{array}$ & 1 & NR & NR & NR & NR & 14.6571 & 121.0380 & Minimal vegetation \\
\hline 16 & La Mesa Dam & 1 & NR & NR & NR & NR & 14.7168 & 121.0731 & Near vegetation \\
\hline 17 & La Mesa Ecopark Pond 1 & 1 & NR & NR & NR & NR & 14.7113 & 121.0756 & Man-made pond \\
\hline 18 & La Mesa Ecopark Pond 2 & 1 & NR & NR & NR & NR & 14.7117 & 121.0759 & Man-made pond \\
\hline 19 & La Mesa Ecopark Lagoon & 1 & NR & NR & NR & NR & 14.7121 & 121.0756 & Fishing lagoon \\
\hline 20 & Creek in Muñoz & 1 & NR & NR & NR & NR & 14.6574 & 121.0157 & $\begin{array}{l}\text { Near residential areas and } \\
\text { commercial establishments }\end{array}$ \\
\hline 21 & Marikina River & 3 & NR & NR & NR & NR & $\begin{array}{l}14.5967 \\
14.6205 \\
14.6342\end{array}$ & $\begin{array}{l}121.0830 \\
121.0828 \\
121.0936\end{array}$ & $\begin{array}{l}\text { Near commercial } \\
\text { establishments }\end{array}$ \\
\hline 22 & Washington SyCip Park pond & 1 & NR & NR & NR & NR & 14.5539 & 121.0180 & Man-made pond \\
\hline 23 & UP Diliman Campus pond & 1 & NR & NR & NR & NR & 14.6547 & 121.0666 & Natural and shallow pond \\
\hline
\end{tabular}

